CLINICAL STUDY

\title{
Vascular endothelial growth factor (VEGF) and its receptor VEGFR-2 are highly expressed in ovarian granulosa cell tumors
}

\author{
Anniina Färkkilä ${ }^{1,2,3}$, Mikko Anttonen ${ }^{2,3}$, Jurate Pociuviene ${ }^{2}$, Arto Leminen ${ }^{2}$, Ralf Butzow ${ }^{3,4}$, \\ Markku Heikinheimo ${ }^{1,3,5}$ and Leila Unkila-Kallio ${ }^{2,3}$ \\ ${ }^{1}$ Pediatric Research Center, Children's Hospital and ${ }^{2}$ Department of Obstetrics and Gynecology, University of Helsinki and Helsinki University Central \\ Hospital, PO Box 20, O0014 Helsinki, Finland, ${ }^{3}$ Program for Women's Health, Biomedicum Helsinki, PO Box 22, O0014 Helsinki, Finland, ${ }^{4}$ Department \\ of Pathology, University of Helsinki and Helsinki University Central Hospital, PO Box 20, 00014 Helsinki, Finland and ${ }^{5}$ Department of Pediatrics, \\ Washington University School of Medicine, St Louis Children's Hospital, St Louis, Missouri 63110, USA
}

(Correspondence should be addressed to M Heikinheimo at Pediatric Research Center, Children's Hospital, University of Helsinki and Helsinki University Central Hospital; Email: markku.heikinheimo@helsinki.fi)

\begin{abstract}
Objective: Ovarian granulosa cell tumors (GCTs) are hormonally active sex cord stromal tumors accounting for $3-5 \%$ of all ovarian cancers. These tumors are generally diagnosed at an early stage but there is a high risk of recurrence, associated with high mortality. Treatment of recurrent GCTs is difficult, and biologically targeted treatment modalities are lacking. GCTs are highly vascularized, and angiogenic factors most probably play a role in their pathology. Vascular endothelial growth factor (VEGF) is a key regulator of tumor angiogenesis, but in GCTs, the role of VEGF and its receptors VEGFR-1 (FLT1) and VEGFR-2 (KDR) remains largely unknown. Our objective is to study the expression of VEGF and its receptors in human GCTs.

Methods: We analyzed GCTs from 106 patients for the expressions of VEGF and its receptors utilizing tumor tissue microarray, tumor mRNA, and patient serum samples.

Results: We found that VEGF and its main biologically active receptor VEGFR-2 were highly expressed in primary and recurrent GCTs, when compared with normal granulosa-lutein cells. The expression of VEGF correlated positively to tumor microvessel density and to VEGFR-2 expression at the protein $(P<0.05)$ and mRNA $(P<0.05)$ levels. In contrast to VEGFR-2, the expression of VEGFR-1 was weak. Tumor VEGF protein expression was not prognostic for recurrence, however, we found high levels of circulating VEGF in the serum of patients with primary GCT.

Conclusions: The results suggest an important role of VEGF and VEGFR-2 in GCT pathology and support the possibility of applying novel VEGF- or VEGFR-2-targeted treatments to patients with GCT.
\end{abstract}

European Journal of Endocrinology 164 115-122

\section{Introduction}

Ovarian granulosa cell tumors (GCTs) are sex cord stromal tumors, which account for $3-5 \%$ of all ovarian cancer (reviewed in (1)). GCTs are hormonally active tumors, producing estrogens and inhibins, and causing the characteristic hormonal signs and symptoms of the disease (2). GCTs are also highly vascularized and hemorrhagic and may present as large abdominal masses with acute abdominal pain (1). The median age of diagnosis in the adult subtype of GCT is $50-54$ years, while the more uncommon juvenile subtype $(5 \%)$ is diagnosed in children and adolescents $(3,4)$. Generally, GCTs are diagnosed at an early stage and are considered to have relatively good prognosis with more than $90 \% 5$-year survival rate (1). These tumors have, however, a high risk of recurrence associated with high mortality $(5,6)$.

Vascular endothelial growth factor (VEGF) is a key regulator of physiological and pathological angiogenesis (reviewed in (7)) and acts by binding to its two tyrosine kinase receptors VEGFR-1 (Fms-like kinase-1, FLT1) and VEGFR-2 (fetal liver kinase-1, FLK1, or kinase-insert domain receptor, KDR) expressed primarily in the endothelial cells (7). In the human ovary, VEGF is crucial for reproductive function, regulating follicular development, angiogenesis, and the development and maintenance of the corpus luteum $(8,9)$. VEGF is expressed in the granulosa cells of preovulatory and ovulatory follicles and most abundantly in the granulosalutein cells of the highly vascularized corpus luteum $(10,11)$. Both VEGFR-1 and VEGFR-2 are expressed in the granulosa-lutein cells in the corpus luteum $(11,12)$, and VEGFR-1 is also expressed in the granulosa cells of preovulatory follicles (11). The expression of the VEGFRs in malignant granulosa cells is undocumented.

VEGF regulates tumor angiogenesis and it is expressed in the majority of human tumors, including those of the ovary (13). Its expression correlates with 
tumor malignancy, and encouraging results have been obtained with anti-VEGF therapy in a wide range of neoplastic diseases $(14,15)$. A humanized anti-VEGF antibody (bevacizumab) is now indicated as a first-line treatment for several metastatic cancers and has shown promise in the treatment of recurrent epithelial ovarian cancer (16). VEGFR targeting tyrosine kinase inhibitors are also being evaluated in phase I-III clinical trials $(17,18)$.

VEGF expression has recently been reported in a small study of GCT patients $(19,20)$, and a few case reports show beneficial effects of bevacizumab on recurrent GCT patients $(20,21)$. The expression of VEGF has, however, not been thoroughly evaluated in primary or recurrent GCTs, and the expression patterns of the VEGF receptors in GCTs remain unknown. We addressed these issues in this study of 106 GCT patients to elucidate the role of VEGF and its receptors in the biology of these ovarian tumors.

\section{Materials and methods}

\section{Patient characteristics}

The ethical committee of the Helsinki University Central Hospital and National Supervisory Authority for Welfare and Health approved this study. We identified 106 GCT patients with available tumor tissue samples diagnosed at the Helsinki University Central Hospital from 1965 to 2009 and collected the clinicopathological data of the patients. The diagnoses were re-evaluated by an experienced pathologist (R B) using immunohistochemical (IHC) markers to confirm the adult GCT diagnoses (22). All available freshly frozen samples $(n=35)$ were tested for the $\mathrm{C} 134 \mathrm{~W}$ mutation in FOXL2 (23-25), and 97\% of the tumors were mutation positive. Tumor subtype, mitotic index, and nuclear atypia were defined by the pathologist (R B), as previously described (22). For controls, normal human ovaries were retrieved from three patients undergoing hystero-oophorectomy for benign indications.

The mean age at diagnosis was 51.5 years (range 19-87 years), and 60 patients $(57 \%)$ were postmenopausal and 46 (43\%) were premenopausal at the time of diagnosis. Of all patients, $30.2 \%(n=32)$ had a recurrent disease, with a mean follow-up time of 13.7 years (range 0.1-37.8 years). The Kaplan-Meier analysis of recurrence was performed on 76 patients with available tissue samples, with a mean follow-up time of 14.7 years (range $0.7-33.5$ years). GCT patient and tumor sample characteristics are described in detail in Table 1.

\section{Tumor tissue microarray}

We constructed a tumor tissue microarray containing four cores from each tumor in duplicates as described previously $(22,26)$. Seventy-nine primary and 12 recurrent GCT samples were available for this tissue array and for consecutive IHC analysis.

\section{Immunohistochemistry}

Paraffin-embedded sections of the microarray and normal human ovaries were subjected to IHC for the expressions of VEGF (A-20, sc-152, Santa Cruz

Table 1 Patient and tumor sample characteristics. Mean age, menopause (MP) status, tumor size and stage are reported at the time of primary granulosa cell tumor diagnosis, i.e. the time of the primary tumor operation.

\begin{tabular}{|c|c|c|c|c|c|c|c|}
\hline & & \multicolumn{6}{|c|}{ Sample type $(n)$} \\
\hline & & \multicolumn{2}{|c|}{$\mathrm{IHC}(91)$} & \multicolumn{2}{|c|}{ mRNA (35) } & \multicolumn{2}{|c|}{ Serum (12) } \\
\hline & & $\mathrm{P}(79)$ & $\mathrm{R}(12)$ & $\mathrm{P}(30)$ & $\mathrm{R}(5)$ & $\mathrm{P}(7)$ & $\mathrm{R}(5)$ \\
\hline Mean age, year (range) & & $51.8(19-20)$ & $44.7(26-65)$ & $52.5(27-76)$ & $39.8(29-49)$ & $56.4(51-64)$ & $39.8(29-49)$ \\
\hline \multirow[t]{2}{*}{ MP status } & Pre-MP & 36 & 7 & 11 & 5 & 2 & 5 \\
\hline & Post MP & 43 & 5 & 19 & 0 & 5 & 0 \\
\hline \multirow[t]{6}{*}{ Stage } & Stage I & 70 & & 26 & & 7 & \\
\hline & la & 49 & & 19 & & 4 & \\
\hline & $\mathrm{lb}$ & 1 & & 0 & & 0 & \\
\hline & Ic & 20 & & 7 & & 3 & \\
\hline & Stage II & 6 & & 3 & & 0 & \\
\hline & Stage III & 3 & & 1 & & 0 & \\
\hline \multirow[t]{2}{*}{ Tumor size } & $<10 \mathrm{~cm}$ & 48 & 9 & 17 & 4 & 3 & 4 \\
\hline & $>10 \mathrm{~cm}$ & 31 & 3 & 13 & 1 & 4 & 1 \\
\hline \multirow[t]{2}{*}{ Tumor subtype } & Differentiated & 55 & 3 & 19 & 3 & 3 & 3 \\
\hline & Sarcomatoid & 24 & 9 & 11 & 2 & 4 & 2 \\
\hline \multirow[t]{2}{*}{ Nuclear atypia } & High & 61 & 9 & 24 & 5 & 4 & 5 \\
\hline & Low & 18 & 3 & 6 & 0 & 3 & 0 \\
\hline \multirow[t]{2}{*}{ Mitotic index } & High & 59 & 7 & 21 & 4 & 1 & 4 \\
\hline & Low & 20 & 5 & 9 & 1 & 6 & 1 \\
\hline \multirow[t]{2}{*}{ Recurrence } & No & 59 & & 25 & & 7 & \\
\hline & Yes & 20 & & 5 & & 0 & \\
\hline
\end{tabular}

$\mathrm{P}$, primary tumors; R, recurrent tumors; IHC, immunohistochemistry. 
Biotechnology, Santa Cruz, CA, USA), VEGFR-1 (C17, sc-316, Santa Cruz Biotechnology), and VEGFR-2 (A-3, sc-6251, Santa Cruz Biotechnology) as previously described (22). In control experiments, nonimmune serum replaced the primary antibody. The intensity of staining was analyzed from the four cores of each tumor as a consensus of two researchers ( $\mathrm{A} \mathrm{F}$ and $\mathrm{M} \mathrm{A}$ ). The staining patterns of VEGF, VEGFR-1, and VEGFR-2 were homogenous, and the immunoreactivities of the tumor cells were compared with those of the granulosa-lutein cells of the normal ovary. The tumors were further divided into two groups with staining intensities being either 'high' or 'low', the latter group including also the tumors that remained negative. The blood vessels were visualized by staining for blood endothelial marker CD34 (mouse-anti-human CD34, M7165, DAKO, Glostrup, Denmark) and counted in duplicates per visual field from the four cores of each tumor. Tumor microvessel density (MVD) was graded as 'high' with $\geq 60$ vessels per visual field and as 'low' with $<60$ per visual field.

\section{Quantitative real-time PCR}

The RNA was isolated from freshly frozen tumor samples of 30 primary and 5 recurrent GCTs according to the manufacturer's instructions (Nucleospin RNA/ Protein kit, catalog no. 740 933.250, Macherey-Nagel, Düren, Germany) and further purified with RNA purification kit (Nucleospin RNA Clean up kit, catalog no. 740 948.50). First-strand cDNA synthesis was performed according to the manufacturer's instructions from $0.8 \mu \mathrm{g}$ total RNA using SYBR Green RT-PCR reagents and random hexamers (Applied Biosystems, Foster City, CA, USA). The following primers were used for real-time PCR: for VEGF, forward 5'-TGCAGATTATGCGGATCAAACC, reverse 5'-TGCATTCACATTTGTTGTGCTGTAG; for VEGFR-2, forward 5'-GGAAGCTCCTGAAGATCTGT, reverse 5'-GAGGATATTTCGTGCCGC; for GAPDH control, forward 5'-TCATTTCCTGGTATGACAACG, reverse $5^{\prime}$-TTACTCCTTGGAGGCCATGT. Standard curve method was applied using purified mRNA from an established human GCT cell line (KGN) (27) as standard. All analyses were performed in triplicate with an ABI PRISM 7700 sequence detection system (Applied Biosystems) according to the manufacturer's instructions. Quantitative real-time PCR of VEGFR-1 was not conducted due to the minimal expression in semiquantitative PCR (data not shown).

\section{Serum analyses}

Serum samples were obtained from 12 patients at the time of diagnosis of the primary $(n=7)$ or recurrent $(n=5)$ GCT. Serum samples were prepared and stored at $-80{ }^{\circ} \mathrm{C}$ until analysis and were analyzed in duplicates with ELISA (R\&D Systems, Minneapolis, MN, USA) according to the manufacturer's instructions.
According to the manufacturer, the mean serum VEGF in healthy subjects is $220 \mathrm{pg} / \mathrm{ml}$ and the range is $62-707 \mathrm{pg} / \mathrm{ml}$.

\section{Statistical analysis}

Statistical analysis was performed with JMP software (JMP 7.0.1, SAS Institute Inc., Cary, NC, USA) and the possible correlations were tested with Student's $t$-test, $\chi^{2}$, and Fischer's exact test or simple regression when appropriate. The Kaplan-Meier analysis was performed according to the methodology, using the time from diagnosis to first recurrence as the end point. Log-rank test was applied to compare the differences between the groups. $P$ value $<0.05$ was considered statistically significant.

\section{Results \\ VEGF and its receptors VEGFR-1 and VEGFR-2 are expressed in human GCTs}

IHC staining for VEGF, VEGFR-1, VEGFR-2, and CD34 is illustrated in Fig. 1. The staining for VEGF was observed in the cytoplasm of tumor cells with even distribution across the tumor cells and also in the endothelial lining of tumor blood vessels (Fig. 1A, higher inset in A). Staining for VEGFR-1 was less pronounced in the tumor cell cytoplasm and membranes, and the expression was also detected in the tumor blood vessel walls (Fig. 1B, higher inset in B). VEGFR-2, however, was strongly expressed in GCT tumor cells, mostly on the tumor cell membranes (Fig. 1C), and also in the tumor blood vessel
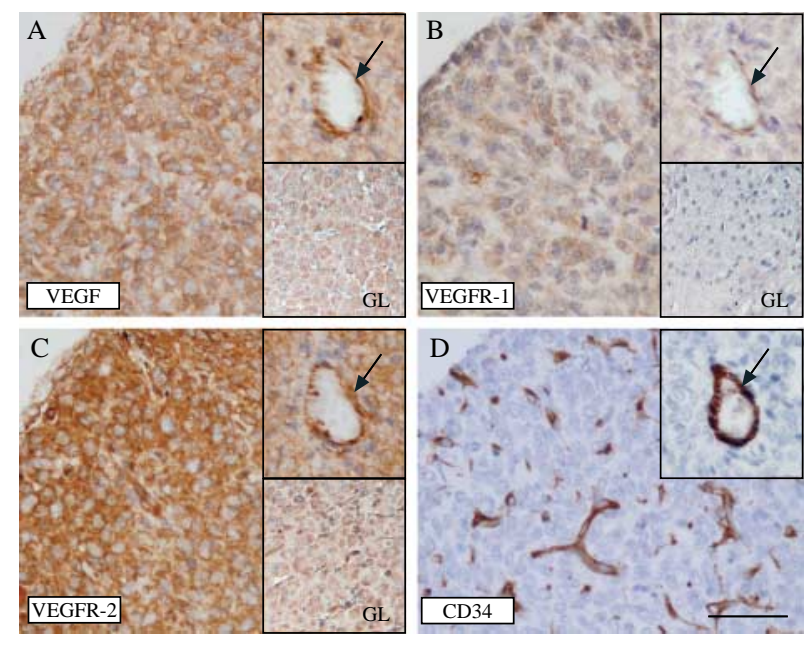

Figure 1 VEGF and its receptors VEGFR-1 and VEGFR-2 are expressed in GCTs. The staining patterns of GCTs are shown for VEGF (A), VEGFR-1 (B), VEGFR-2 (C), and CD-34 (D). Note the expression of VEGF and VEGFR-2 in the tumor cells (A and $C)$ and in the blood vessels (higher insets in $A$ and $C$ ). Arrows indicate blood vessels in higher insets in (A-D). GL indicates granulosalutein cells in the corpus luteum of the normal human ovary (lower insets in $A-C)$. Original magnification $\times 20$, scale bar $100 \mu \mathrm{m}$. 
walls (Fig. 1C, higher inset in C). For comparison, normal human ovaries were stained for VEGF, VEGFR-1, and VEGFR-2 (lower insets in Fig. 1A-C). In accordance with previous findings $(11,12)$, VEGF and VEGFR-2 were expressed in the granulosa-lutein cells of the corpus luteum (lower insets in Fig. 1A and C). VEGFR-1 expression in the granulosa-lutein cells was, however, negligible (lower inset in Fig. 1B).

\section{VEGF protein expression correlates with VEGFR-1 and VEGFR-2 protein expression, and tumor MVD}

The intensities of staining in the tumor cells were evaluated in 79 primary and 12 recurrent GCTs, and the tumors were divided into high- and low-stained groups (Table 2). The intensity of staining in normal granulosalutein cells represented the low expression group for VEGF, VEGFR-1, and VEGFR-2. Of all tumors, 65 (74\%) stained high for VEGF, whereas VEGF staining was low in $23(26 \%)$ of the tumors. Only six $(7 \%)$ tumors (five primary and one recurrent) were negative for VEGF. Staining for VEGFR-1 was generally weak (Table 2) with $82 \%$ of all tumors exhibiting low staining, and $44(48 \%)$ tumors (40 primary and 4 recurrent) remained negative. The staining for VEGFR-2 was more intense, being high in $82(93 \%)$ of the tumors and low in $6(7 \%)$ of all tumors respectively (Table 2). Only one (1\%) primary tumor was negative for VEGFR-2. The number of microvessels varied from 6 to 171 (mean 45) per visual field (Table 2). There were no statistically significant differences in the staining patterns of primary and recurrent tumors. In all GCTs, the expression of VEGFR-1 and VEGFR-2 protein correlated positively to that of VEGF $(P<0.05$; Table 3$)$. The correlation between VEGFR-1 and VEGFR-2 expressions did not reach statistical significance probably due to small numbers in the different groups (Table 2). We also found that tumor MVD correlated positively to VEGF expression as analyzed in all tumors (Table 3).

Table 2 VEGF protein expression correlates positively to the expressions of VEGFR-1, VEGFR-2, and to tumor MVD. The intensity of staining and MVD were divided into groups with high or low expression. Note that high expression was seen in $74 \%$ of the tumors for VEGF, $82 \%$ for VEGFR-2, and only $16 \%$ for VEGFR-1. There were no statistical differences between the expression levels of primary and recurrent tumors.

\begin{tabular}{llccc}
\hline & & \multicolumn{3}{c}{ Tumors $(n)$} \\
\cline { 3 - 5 } & Groups & $\mathrm{P}(n=79)$ & $\mathrm{R}(n=12)$ & Tot $(n=91)$ \\
\hline VEGF & High & $56(73)$ & $9(82)$ & $65(74)$ \\
& Low & $21(27)$ & $2(18)$ & $23(26)$ \\
VEGFR-1 & High & $11(14)$ & $5(45)$ & $16(18)$ \\
& Low & $66(86)$ & $6(55)$ & $72(82)$ \\
VEGFR-2 & High & $71(92)$ & $11(100)$ & $82(93)$ \\
& Low & $6(8)$ & $0(0)$ & $6(7)$ \\
MVD & High & $19(24)$ & $6(50)$ & $25(28)$ \\
& Low & $60(76)$ & $6(50)$ & $66(72)$ \\
\hline
\end{tabular}

$\mathrm{P}$, primary; $\mathrm{R}$, recurrent; Tot, all tumors.
Table 3 Correlations of protein expressions in all GCTs. Note the positive correlation of VEGF expression to the expressions of VEGFR-1 and VEGFR-2, and to MVD.

\begin{tabular}{lllll}
\hline & VEGF & VEGFR-1 & VEGFR-2 & MVD \\
\hline VEGF & & + & + & + \\
VEGFR-1 & + & NS & NS & NS \\
VEGFR-2 & + & NS & NS & NS \\
MVD & + & NS & \\
\hline
\end{tabular}

+ , positive correlation with $P<0.05$; NS, not significant.

\section{VEGF protein expression is not prognostic for recurrence}

In the primary tumors, we could not find any correlations between the expressions of VEGF, VEGFR-1, or VEGFR-2 and primary tumor characteristics (tumor stage, subtype, tumor size, nuclear atypia, and mitotic index) or patient characteristics (age at diagnosis and menopausal status). Neither were there any correlations between VEGF, VEGFR-1, or VEGFR-2 expressions and tumor characteristics (tumor size, subtype, nuclear atypia, and mitotic index) in the recurrent tumors. When all GCTs were analyzed, there was, however, a positive correlation between tumor MVD and tumor mitotic index $(P<0.05)$, but not between MVD and other tumor characteristics. We also analyzed whether VEGF protein expression in the primary tumor could be prognostic for the recurrence in patients with GCT. The time to first recurrence is shown by the Kaplan-Meier analysis as to primary tumor VEGF expression in 76 patients (Fig. 2). There were 12 recurrences in the high VEGF group $(n=55)$ and 6 in the low VEGF-expressing group $(n=21)$ and the recurrence probability was similar in these groups.

\section{VEGF and VEGFR-2 mRNA expressions corre- late positively in primary and recurrent GCTs}

We next analyzed the mRNA levels of VEGF and VEGFR-2 with quantitative real-time PCR in 35 GCTs (30 primary and 5 recurrent). We found that VEGF and VEGFR-2 mRNA expressions were expressed in the primary and recurrent GCTs (Fig. 3A and B), without any statistical difference between the primary and recurrent GCTs. The mRNA expression of VEGF correlated positively to that of VEGFR-2 (Fig. 3C). The mRNA expression of VEGF or VEGFR-2 in the primary or recurrent tumors did not show significant correlations to tumor or patient characteristics.

\section{Circulating VEGF is present in high quantities in the serum of patients with primary GCT}

We evaluated the serum levels of VEGF from seven primary and five recurrent GCT patients. At the time of diagnosis, the mean serum VEGF levels tended to be 


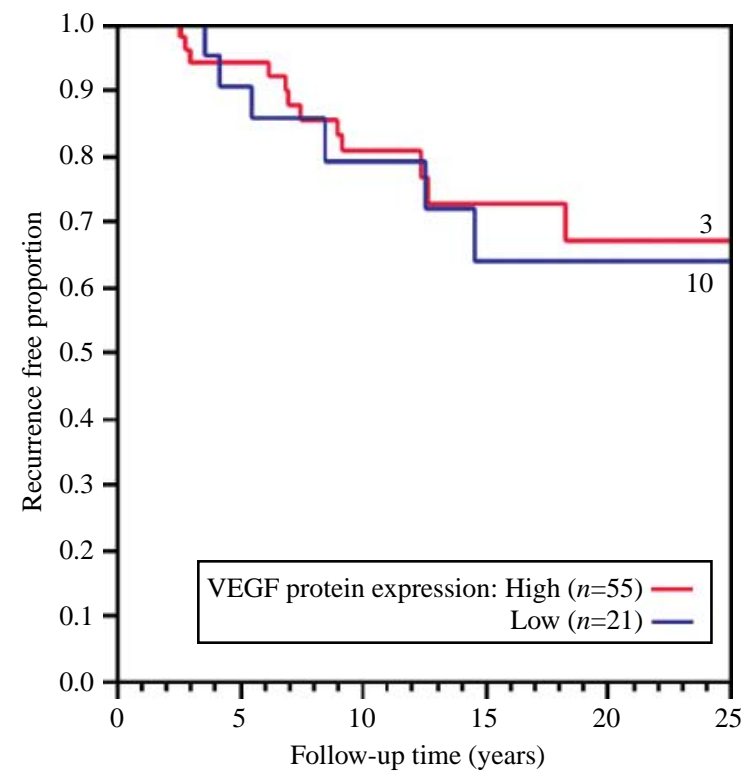

Figure 2 VEGF protein expression is not prognostic for recurrence. The Kaplan-Meier curves for recurrence in the high (red line, $n=55$ ) and low (blue line, $n=21$ ) VEGF expression groups. The recurrence probability was similar between the groups.

higher in primary GCT patients (mean $557 \mathrm{pg} / \mathrm{ml}$, median $411 \mathrm{pg} / \mathrm{ml}$, range $107-1020 \mathrm{pg} / \mathrm{ml}$ ) than in recurrent GCT patients (mean $219 \mathrm{pg} / \mathrm{ml}$, median $149 \mathrm{pg} / \mathrm{ml}$, range $40-539 \mathrm{pg} / \mathrm{ml}$; Fig. 4), although there was no statistical difference between these groups $(P=0.097)$. The serum VEGF levels did not correlate to the tumor size or stage, and there was no statistical difference in the tumor size between the primary and recurrent tumors.

\section{Discussion}

Tumor angiogenesis is a critical step in cancer progression, and anti-angiogenic cancer treatments have been extensively studied over the past decade. VEGF, being one of the main pro-angiogenic growth factors in many cancers, was the first to be targeted and anti-VEGF treatments are now in wide clinical use (15). Recently, the VEGF receptors have also shown promise as targets for anticancer drugs $(28,29)$. So far, little has been known about the expression of VEGF and its receptors in GCTs. We show that VEGF and its receptors are expressed in both primary and recurrent GCTs, and these findings provide the biological basis for the development and implementation of biologically targeted treatments to patients with GCT.

In accordance with previous findings $(19,20)$, we found that VEGF was abundantly expressed in GCTs, with almost all tumors (93\%) staining positive for VEGF. VEGF was expressed homogenously in the cytoplasm of the tumor cells and also in the blood vessel endothelium. The expression of VEGF protein was higher in GCTs than in the nonmalignant granulosa cells, indicating a role for VEGF in these tumors. The expression levels were similar in primary and recurrent GCTs, both at the protein and mRNA levels. Although we found no correlations between VEGF expression and tumor aggressiveness, the fact that both primary and recurrent tumors express VEGF at high levels suggests an important role of VEGF in the GCT pathology.

VEGFR-2, the main mediator of VEGF function, is usually expressed only in the blood vessel endothelial cells (30). We found that compared with normal granulosa-lutein cells, VEGFR-2 protein is highly expressed in the granulosa tumor cells. In normal endothelial cells, VEGF exposure leads to the downregulation of the VEGFRs (31). This regulatory function is, however, lost in VEGFR-2-expressing cancer cells (32), and the previous findings from ovarian (33) and breast (34) cancer cells suggest a survival-promoting VEGF-VEGFR-2 autoloop, which can be inhibited with anti-VEGF treatment (bevacizumab) (35). In our analysis, the expression of VEGFR-2 protein and mRNA correlated with those of VEGF, implicating an autocrine role of VEGF also in GCTs. Furthermore, VEGFR-2 expression did not correlate to tumor MVD, reflecting the strong expression in the tumor cells, and further indicating that the role of VEGFR-2 in GCTs may be independent of the tumor vasculature. Although VEGFR-2 expression did not correlate to tumor aggressiveness, the remarkably high expression suggests a role of VEGF-VEGFR-2 signaling in GCTs that is worth further studies.

In contrast to VEGFR-2, the expression of VEGFR-1 in GCTs was low. Furthermore, VEGFR-1 is usually considered to function as a decoy receptor for VEGF, and it is not markedly phosphorylated upon VEGF binding (36). The prognostic role of VEGFR-1 in tumors has remained controversial $(37,38)$. In the search for novel anticancer treatments, some of the new smallmolecule tyrosine kinase inhibitors are, however,
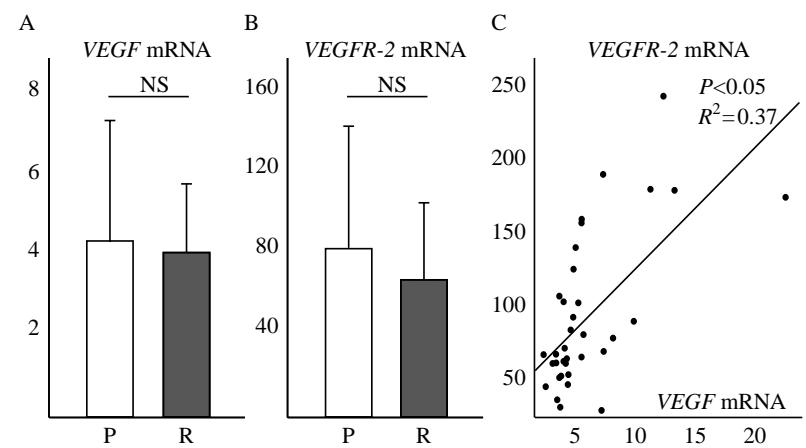

Figure 3 VEGFmRNA expression correlates positively to VEGFR-2 mRNA expression. Quantitative real-time PCR was performed on the mRNA isolated from 30 primary $(P$ in $A$ and $B$ ) and 5 recurrent ( $R$ in $A$ and $B$ ) GCTs. Note the similar expression of VEGF and VEGFR-2 in primary and recurrent GCTs, and the positive correlation of VEGF mRNA expression to that of VEGFR-2 in primary and recurrent tumors (C). 


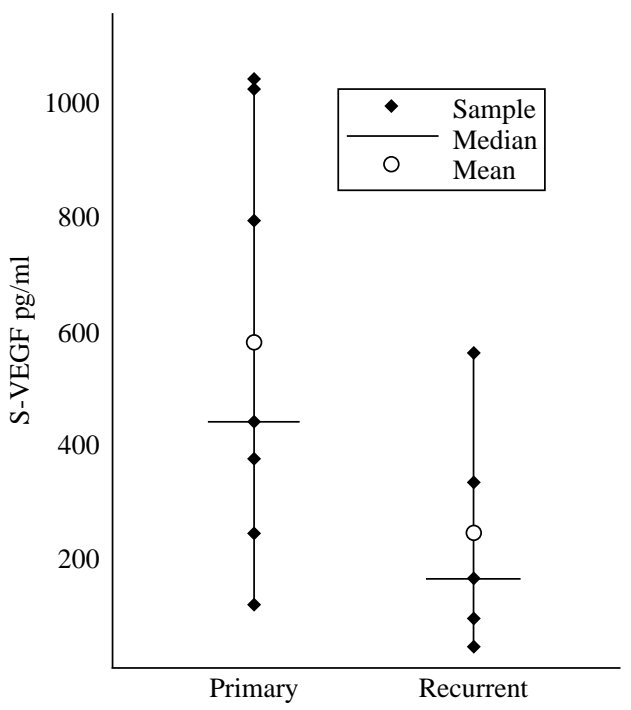

Figure 4 High level of VEGF is present in the serum of patients with primary GCT. VEGF was measured at the time of diagnosis from the serum of patients with primary $(n=7)$ and recurrent $(n=5)$ GCT. The mean VEGF tended to be higher in the primary GCT samples than in the recurrent GCT samples, although the difference was not statistically significant $(P=0.097)$.

designed also to inhibit VEGFR-1 (17). We found high VEGFR-1 protein expression in a minority of primary GCTs, and there was no correlation between VEGFR-1 expression and tumor aggressiveness.

As an indirect indicator of tumor angiogenesis, MVD has been shown to be of prognostic significance in ovarian cancer (39), but its role in GCTs is still unknown (40). Previous data suggest that mitotic index is a prognostic marker in GCTs (41-43), but this has not been found in all studies $(22,40)$. We found that VEGF protein expression correlated positively to tumor MVD, independent of tumor size or stage. High tumor MVD also correlated to high tumor mitotic index, implicating enhanced angiogenesis in the tumors with an active growth. These results implicate a role of VEGF-driven angiogenesis in the growing GCT and offer a possibility to implement biological adjuvant treatments on the actively growing GCTs with high mitotic index, even regardless of tumor size or stage.

It was of interest to evaluate whether VEGF and its receptors can be used in delineating the prognosis of GCT patients. We found no correlations between primary tumor VEGF, VEGFR-1, and VEGFR-2 protein or mRNA expressions and recurrence, and neither did primary tumor VEGF expression predict recurrence-free survival. Thus, based on this study, these parameters are not likely to be of value in the prognostic evaluation of GCT patients. In our analysis, circulating mean VEGF levels in primary tumor patients tended to be higher than in patients with recurrent disease. This may be due to increased VEGF producing tumor burden in primary compared with recurrent GCTs. The mean circulating
VEGF in primary GCT patients is similar to that observed in epithelial ovarian cancer patients $(44,45)$, but the range of circulating VEGF is wide, even in healthy subjects (46). A larger study of GCT patients and healthy control subjects needs to be studied to evaluate the clinical value of serum VEGF in these patients.

Surgery is the first-line treatment in primary GCTs, but the treatment of recurrent GCTs consists of a combination of surgery and chemotherapy. Recurrencies are rather common (reaching 30\% in this study) and often present in locations where surgical removal is not feasible $(5,47)$. Despite the developments in conventional chemotherapeutic combination treatments, mortality in recurrent GCT is high $(5,6)$, and thus the most challenges rise in the treatment of recurrent GCTs. Recently, anti-VEGF (bevacizumab) monotherapy was shown to be highly effective in a retrospective study of eight patients with recurrent GCTs (20). In addition, markedly reduced ascites formation was reported with bevazicumab treatment in a patient with recurrent GCT (21), reflecting the role of tumor-derived VEGF in the formation of cancerrelated ascites $(48,49)$. Considering our findings on the high expression of VEGF and VEGFR-2 also in recurrent GCTs, these patients could benefit from the introduction of VEGF- or VEGFR-2-targeted anticancer drugs, in combination with traditional treatments. To test this, however, large multicenter clinical trials are required.

In conclusion, our findings implicate a role of VEGF and its receptor VEGFR-2 in GCT pathogenesis and support the targeting of VEGF and VEGFR-2 in the validation of new treatments for GCT patients.

\section{Declaration of interest}

The authors declare that there is no conflict of interest that could be perceived as prejudicing the impartiality of the research reported.

\section{Funding}

This work was supported by Academy of Finland, Finnish Cancer Organizations, Helsinki University Central Hospital Research Funds, Sigrid Juselius Foundation, and National Clinical Graduate School.

\section{Acknowledgements}

We thank Ms Taru Jokinen, Ms Gynel Arifdshan, and Ms Teija Karkkulainen for excellent technical assistance, and B.Sci Marjut Kauppinen for critical reading of the manuscript.

\section{References}

1 Schumer ST \& Cannistra SA. Granulosa cell tumor of the ovary. Journal of Clinical Oncology 200321 1180-1189. (doi:10.1200/ JCO.2003.10.019)

2 Unkila-Kallio L, Tiitinen A, Wahlstrom T, Lehtovirta P \& Leminen A. Reproductive features in women developing ovarian granulosa cell tumour at a fertile age. Human Reproduction 2000 15 589-593. (doi:10.1093/humrep/15.3.589) 
3 Pectasides D, Pectasides E \& Psyrri A. Granulosa cell tumor of the ovary. Cancer Treatment Reviews 200834 1-12. (doi:10.1016/ j.ctrv.2007.08.007)

4 Merras-Salmio L, Vettenranta K, Mottonen M \& Heikinheimo M. Ovarian granulosa cell tumors in childhood. Pediatric Hematology and Oncology 200219 145-156. (doi:10.1080/0888001027535 41297)

5 Fujimoto T, Sakuragi N, Okuyama K, Fujino T, Yamashita K, Yamashiro S, Shimizu M \& Fujimoto S. Histopathological prognostic factors of adult granulosa cell tumors of the ovary. Acta Obstetricia et Gynecologica Scandinavica 200180 1069-1074.

6 Cronje HS, Niemand I, Bam RH \& Woodruff JD. Review of the granulosa-theca cell tumors from the emil Novak ovarian tumor registry. American Journal of Obstetrics and Gynecology $19991 \mathbf{1 8 0}$ 323-327. (doi:10.1016/S0002-9378(99)70207-3)

7 Ferrara N, Gerber HP \& LeCouter J. The biology of VEGF and its receptors. Nature Medicine 20039 669-676. (doi:10.1038/ nm0603-669)

8 Lam PM \& Haines C. Vascular endothelial growth factor plays more than an angiogenic role in the female reproductive system. Fertility and Sterility $2005 \mathbf{8 4}$ 1775-1778. (doi:10.1016/ j.fertnstert.2005.05.059)

9 Geva E \& Jaffe RB. Role of vascular endothelial growth factor in ovarian physiology and pathology. Fertility and Sterility $2000 \mathbf{7 4}$ 429-438. (doi:10.1016/S0015-0282(00)00670-1)

10 Kamat BR, Brown LF, Manseau EJ, Senger DR \& Dvorak HF. Expression of vascular permeability factor/vascular endothelial growth factor by human granulosa and theca lutein cells. Role in corpus luteum development. American Journal of Pathology 1995 146 157-165.

11 Otani N, Minami S, Yamoto M, Shikone T, Otani H, Nishiyama R, Otani T \& Nakano R. The vascular endothelial growth factor/fmslike tyrosine kinase system in human ovary during the menstrual cycle and early pregnancy. Journal of Clinical Endocrinology and Metabolism 199984 3845-3851. (doi:10.1210/jc.84.10.3845)

12 Sugino N, Kashida S, Takiguchi S, Karube A \& Kato H. Expression of vascular endothelial growth factor and its receptors in the human corpus luteum during the menstrual cycle and in early pregnancy. Journal of Clinical Endocrinology and Metabolism 2000 85 3919-3924. (doi:10.1210/jc.85.10.3919)

13 Olson TA, Mohanraj D, Carson LF \& Ramakrishnan S. Vascular permeability factor gene expression in normal and neoplastic human ovaries. Cancer Research 199454 276-280.

14 Ferrara N. Vascular endothelial growth factor as a target for anticancer therapy. Oncologist 20049 (Supplement 1) 2-10. (doi:10.1634/theoncologist.9-suppl_1-2)

15 Heath VL \& Bicknell R. Anticancer strategies involving the vasculature. Nature Reviews. Clinical Oncology 20096 395-404. (doi:10.1038/nrclinonc.2009.52)

16 Han ES \& Monk BJ. Bevacizumab in the treatment of ovarian cancer. Expert Review of Anticancer Therapy 20077 1339-1345. (doi:10.1586/14737140.7.10.1339)

17 Matulonis UA, Berlin S, Ivy P, Tyburski K, Krasner C, Zarwan C, Berkenblit A, Campos S, Horowitz N, Cannistra SA, Lee H, Lee J, Roche M, Hill M, Whalen C, Sullivan L, Tran C, Humphreys BD \& Penson RT. Cediranib, an oral inhibitor of vascular endothelial growth factor receptor kinases, is an active drug in recurrent epithelial ovarian, fallopian tube, and peritoneal cancer. Journal of Clinical Oncology 200927 5601-5606. (doi:10.1200/JCO.2009. 23.2777)

18 Natale RB, Bodkin D, Govindan R, Sleckman BG, Rizvi NA, Capo A, Germonpre P, Eberhardt WE, Stockman PK, Kennedy SJ \& Ranson M. Vandetanib versus gefitinib in patients with advanced non-small-cell lung cancer: results from a two-part, double-blind, randomized phase II study. Journal of Clinical Oncology 200927 2523-2529. (doi:10.1200/JC0.2008.18.6015)

19 Schmidt M, Kammerer U, Segerer S, Cramer A, Kohrenhagen N, Dietl J \& Voelker HU. Glucose metabolism and angiogenesis in granulosa cell tumors of the ovary: activation of Akt, expression of M2PK, TKTL1 and VEGF. European Journal of Obstetrics, Gynecology, and Reproductive Biology 2008139 72-78. (doi:10. 1016/j.ejogrb.2008.02.009)

20 Tao X, Sood AK, Deavers MT, Schmeler KM, Nick AM, Coleman RL, Milojevic L, Gershenson DM \& Brown J. Antiangiogenesis therapy with bevacizumab for patients with ovarian granulosa cell tumors. Gynecologic Oncology 2009114 431-436. (doi:10.1016/j.ygyno.2009.04.021)

21 Kesterson JP, Mhawech-Fauceglia P \& Lele S. The use of bevacizumab in refractory ovarian granulosa-cell carcinoma with symptomatic relief of ascites: a case report. Gynecologic Oncology 2008111 527-529. (doi:10.1016/j.ygyno.2008.07. 015)

22 Anttonen M, Unkila-Kallio L, Leminen A, Butzow R \& Heikinheimo M. High GATA-4 expression associates with aggressive behavior, whereas low anti-Mullerian hormone expression associates with growth potential of ovarian granulosa cell tumors. Journal of Clinical Endocrinology and Metabolism 2005 90 6529-6535. (doi:10.1210/jc.2005-0921)

23 Shah SP, Kobel M, Senz J, Morin RD, Clarke BA, Wiegand KC, Leung G, Zayed A, Mehl E, Kalloger SE, Sun M, Giuliany R, Yorida E, Jones S, Varhol R, Swenerton KD, Miller D, Clement PB, Crane C, Madore J, Provencher D, Leung P, DeFazio A, Khattra J, Turashvili G, Zhao Y, Zeng T, Glover JN, Vanderhyden B, Zhao C, Parkinson CA, Jimenez-Linan M, Bowtell DD, Mes-Masson AM, Brenton JD, Aparicio SA, Boyd N, Hirst M, Gilks CB, Marra M \& Huntsman DG. Mutation of FOXL2 in granulosa-cell tumors of the ovary. New England Journal of Medicine 2009360 2719-2729. (doi:10.1056/NEJMoa0902542)

24 Jamieson S, Butzow R, Andersson N, Alexiadis M, Unkila-Kallio L, Heikinheimo M, Fuller PJ \& Anttonen M. The FOXL2 C134W mutation is characteristic of adult granulosa cell tumors of the ovary. Modern Pathology 201023 1477-1485. (doi:10.1038/ modpathol.2010.145)

25 Kim MS, Hur SY, Yoo NJ \& Lee SH. Mutational analysis of FOXL2 codon 134 in granulosa cell tumour of ovary and other human cancers. Journal of Pathology 2010221 147-152. (doi:10.1002/ path.2688)

26 Kononen J, Bubendorf L, Kallioniemi A, Barlund M, Schraml P, Leighton S, Torhorst J, Mihatsch MJ, Sauter G \& Kallioniemi OP. Tissue microarrays for high-throughput molecular profiling of tumor specimens. Nature Medicine $1998 \mathbf{4}$ 844-847. (doi:10. 1038/nm0798-844)

27 Nishi Y, Yanase T, Mu Y, Oba K, Ichino I, Saito M, Nomura M, Mukasa C, Okabe T, Goto K, Takayanagi R, Kashimura Y, Haji M \& Nawata H. Establishment and characterization of a steroidogenic human granulosa-like tumor cell line, KGN, that expresses functional follicle-stimulating hormone receptor. Endocrinology 2001142 437-445. (doi:10.1210/en.142.1.437)

28 Schiller JH, Larson T, Ou SH, Limentani S, Sandler A, Vokes E, Kim S, Liau K, Bycott P, Olszanski AJ \& von Pawel J. Efficacy and safety of axitinib in patients with advanced non-small-cell lung cancer: results from a phase II study. Journal of Clinical Oncology 200927 3836-3841. (doi:10.1200/JCO.2008.20.8355)

29 Drevs J, Siegert P, Medinger M, Mross K, Strecker R, Zirrgiebel U, Harder J, Blum H, Robertson J, Jurgensmeier JM, Puchalski TA, Young H, Saunders O \& Unger C. Phase I clinical study of AZD2171, an oral vascular endothelial growth factor signaling inhibitor, in patients with advanced solid tumors. Journal of Clinical Oncology 200725 3045-3054. (doi:10.1200/JC0.2006.07. 2066)

30 Tammela T, Enholm B, Alitalo K \& Paavonen K. The biology of vascular endothelial growth factors. Cardiovascular Research 2005 65 550-563. (doi:10.1016/j.cardiores.2004.12.002)

31 Wang D, Donner DB \& Warren RS. Homeostatic modulation of cell surface KDR and Flt1 expression and expression of the vascular endothelial cell growth factor (VEGF) receptor mRNAs by VEGF. Journal of Biological Chemistry 2000275 15905-15911. (doi:10. 1074/jbc.M001847200) 
32 Masood R, Cai J, Zheng T, Smith DL, Hinton DR \& Gill PS. Vascular endothelial growth factor (VEGF) is an autocrine growth factor for VEGF receptor-positive human tumors. Blood 200198 1904-1913. (doi:10.1182/blood.V98.6.1904)

33 Sher I, Adham SA, Petrik J \& Coomber BL. Autocrine VEGF-A/KDR loop protects epithelial ovarian carcinoma cells from anoikis. International Journal of Cancer 2009124 553-561. (doi:10.1002/ ijc. 23963)

34 Weigand M, Hantel P, Kreienberg R \& Waltenberger J. Autocrine vascular endothelial growth factor signalling in breast cancer. Evidence from cell lines and primary breast cancer cultures in vitro. Angiogenesis 20058 197-204. (doi:10.1007/s10456005-9010-0)

35 Sims TL, Williams RF, Ng CY, Rosati SF, Spence Y \& Davidoff AM. Bevacizumab suppresses neuroblastoma progression in the setting of minimal disease. Surgery 2008144 269-275. (doi:10.1016/ j.surg.2008.04.009)

36 Park JE, Chen HH, Winer J, Houck KA \& Ferrara N. Placenta growth factor. Potentiation of vascular endothelial growth factor bioactivity, in vitro and in vivo, and high affinity binding to Flt-1 but not to Flk-1/KDR. Journal of Biological Chemistry 1994269 25646-25654.

37 Secord AA, Darcy KM, Hutson A, Lee PS, Havrilesky LJ, Grace LA \& Berchuck A. Co-expression of angiogenic markers and associations with prognosis in advanced epithelial ovarian cancer: a Gynecologic Oncology Group study. Gynecologic Oncology 2007 106 221-232. (doi:10.1016/j.ygyno.2007.03.021)

38 Carrillo de Santa Pau E, Arias FC, Caso Pelaez E, Munoz Molina GM, Sanchez Hernandez I, Muguruza Trueba I, Moreno Balsalobre R, Sacristan Lopez S, Gomez Pinillos A \& del Val Toledo Lobo M. Prognostic significance of the expression of vascular endothelial growth factors A, B, C, and D and their receptors R1, $\mathrm{R} 2$, and $\mathrm{R} 3$ in patients with nonsmall cell lung cancer. Cancer 2009115 1701-1712. (doi:10.1002/cncr.24193)

39 Palmer JE, Sant Cassia LJ, Irwin CJ, Morris AG \& Rollason TP. Prognostic value of measurements of angiogenesis in serous carcinoma of the ovary. International Journal of Gynecological Pathology 200726 395-403. (doi:10.1097/pgp.0b013e318063bed7)

40 Juric G, Zarkovic N, Nola M, Tillian M \& Jukic S. The value of cell proliferation and angiogenesis in the prognostic assessment of ovarian granulosa cell tumors. Tumori 200187 47-53.

41 Miller BE, Barron BA, Wan JY, Delmore JE, Silva EG \& Gershenson DM. Prognostic factors in adult granulosa cell tumor of the ovary. Cancer 199779 1951-1955. (doi:10.1002/ (SICI)1097-0142(19970515)79:10<1951::AID-CNCR16>3.0. $\mathrm{CO} ; 2-\mathrm{U})$

42 Fox H. Pathologic prognostic factors in early stage adult-type granulosa cell tumors of the ovary. International Journal of Gynecological Cancer 200313 1-4. (doi:10.1046/j.1525-1438. 2003.13050.x)

43 Malmstrom H, Hogberg T, Risberg B \& Simonsen E. Granulosa cell tumors of the ovary: prognostic factors and outcome. Gynecologic Oncology 199452 50-55. (doi:10.1006/gyno.1994.1010)

44 Hefler LA, Zeillinger R, Grimm C, Sood AK, Cheng WF, Gadducci A, Tempfer CB \& Reinthaller A. Preoperative serum vascular endothelial growth factor as a prognostic parameter in ovarian cancer. Gynecologic Oncology $2006 \mathbf{1 0 3}$ 512-517. (doi:10.1016/j.ygyno.2006.03.058)

45 Cooper BC, Ritchie JM, Broghammer CL, Coffin J, Sorosky JI, Buller RE, Hendrix MJ \& Sood AK. Preoperative serum vascular endothelial growth factor levels: significance in ovarian cancer. Clinical Cancer Research 20028 3193-3197.

46 Barton DP, Cai A, Wendt K, Young M, Gamero A \& De Cesare S. Angiogenic protein expression in advanced epithelial ovarian cancer. Clinical Cancer Research 19973 1579-1586.

47 Homesley HD, Bundy BN, Hurteau JA \& Roth LM. Bleomycin, etoposide, and cisplatin combination therapy of ovarian granulosa cell tumors and other stromal malignancies: a Gynecologic Oncology Group study. Gynecologic Oncology 199972 131-137. (doi:10.1006/gyno.1998.5304)

48 Nagy JA, Masse EM, Herzberg KT, Meyers MS, Yeo KT, Yeo TK, Sioussat TM \& Dvorak HF. Pathogenesis of ascites tumor growth: vascular permeability factor, vascular hyperpermeability, and ascites fluid accumulation. Cancer Research 199555 360-368.

49 Kraft A, Weindel K, Ochs A, Marth C, Zmija J, Schumacher P, Unger C, Marme D \& Gastl G. Vascular endothelial growth factor in the sera and effusions of patients with malignant and nonmalignant disease. Cancer 199985 178-187. (doi:10.1002/ (SICI)1097-0142(19990101)85:1 < 178::AID-CNCR25>3.0. $\mathrm{CO} ; 2-7)$

Received 13 October 2010

Accepted 1 November 2010 